\title{
New Qualification Level Description in Malaysian Framework for Equivalence Checking via APEL Process
}

\author{
Noraini Kaprawi ${ }^{1}$, Norfaezah Saparwan ${ }^{2}$, Noor Farhah Muzaimah Mohd \\ Amin*3 \\ ${ }^{1}$ Faculty of Technical and Vocational Education, University Tun Hussein Onn, Batu Pahat, 86400, MALAYSIA
}

DOI: https://doi.org/10.30880/jtet.2019.11.01.003

Received $30^{\text {th }}$ August 2018; Accepted $07^{\text {th }}$ November 2018; Available online $31^{\text {st }}$ March 2019

\begin{abstract}
Accreditation of Prior Experiential Learning (APEL) is a systematic process involving the identification, documentation and assessment of learning based on previous experience. This study is aimed at determining the descriptions of each qualification level within the Malaysian Qualifications Framework (MQF) that can be proposed for use in the research of equivalence between skill and academic of the APEL process. Through this equity research, it can facilitate individual passage from skills to further higher education in the academic. This study used a qualitative approach which involved exploratory methods through document analysis (Malaysian Qualification Framework, Australia Qualification Framework and Europe Qualification Framework) interviews (semi structure) and descriptive survey (score mean and standard deviation) methods through a questionnaire instrument. Based on the information obtained from UTHM, ADTEC, KKTM and IKBN the total population of this study is 97 persons. However, only 54 respondents gave feedback on distributed surveys. The findings show that all description items of each level of qualification proposed in the MQF are best suited to describe learning outcomes for each level. A description that includes three domains (knowledge, skills and competence) can be suggested to stakeholders. This will help individuals from areas of skills to pursue higher education in the academic field through the APEL process.
\end{abstract}

Keywords: Malaysian Qualification Framework; description of qualification framework; qualification level; Accreditation of Prior Experiential Learning (APEL)

\section{Introduction}

Technical and Vocational Education (TVET) is one of the branches of education offered in many countries around the world to provide opportunities for students with a tailored to technology and science education to complement professional and part-time professionals. Mohd Tahir \& Mustafa (2009) said that this Technical and Vocational Education helps students drop out of academic lessons but has the potential to become excellent people in skills and thus generate the nation's economy. In many countries, this education is focused on creating human capital that meets the industry's needs. Hence, Malaysia needs to shift from focus to conventional university education to two separate divisions which also take into account the TVET. The transformation of the higher education system will provide the collective benefits and rights, as well as provide appropriate roles to each stakeholder among them to resume studies at appropriate times of life through formal education, non-formal and informal, to meet the interests and demands of career advancement (Ministry of Education, 2015).

Md Yunos (2010) argues articulation involves two things: career path and other path of study that a student will succeed. In relation to this issue, the development of the education system in Malaysia should not be stuck simply because of the absence of a mechanism that can be used to enable a person to pursue higher education with the knowledge and experience he/she possesses. Based on the experience and skills in the field of study used, they are 
qualified for credit transfer. Mohamad (2002) supported this idea by stating that the experiences gained during work can be in line with the knowledge gained by someone while attending formal education at the university. In order to realize lifelong education and create opportunities for open and flexible education but emphasizing quality, so it's just right to conduct analytical review of the most appropriate assessment method used in Malaysia in recognizing previous learning.

APEL is a method of assessment where students can gain an accreditation from the knowledge, skills and competencies they already got. It is also a process of formal recognition of learning gained from formal, personal and experiential learning. This process requires active thinking and experience analysis and self-assessment profile to extract the learning achieved for measuring learning outcomes. They may use this official accreditation or authorization to enter a study program for a part of the last qualification (e.g diploma or degree) to prevent them repeating the learning they have mastered (Kaprawi, 2011). Hence, a study should be undertaken to establish a credit recognition system framework for previous learning that enables candidates to pursue higher education at Public Higher Education Institutions or Private Institutions of Higher Learning. However, in order to implement the credit accreditation system for learning or previous experience in the field of skills (TVET), an instrument or rubric of equivalence research needs to be developed as has been done by the German state (Musken, 2006). To apply equivalence research, the equivalence checking of the individual should refer to the Malaysian Qualification Framework (MQF) which outlines the learning outcomes that need to be owned according to the qualification level.

However, there are some issues for conducting equivalence research between academic and skills areas where the qualification descriptions in the MQF are not specifically tailored to the knowledge, skills and competences domain as contained in the European Qualifications Framework (EQF). This study was carried out to determine the descriptions of each qualification level within the Malaysian Qualifications Framework that could be proposed for use in the research of equivalence between the fields of academic and skills. This study is based on the objectives that to identify the descriptions of each qualifying stage within the MQF that may be proposed for use in research of the equivalence between skills and the academic via APEL process.

\section{Methodology}

In selecting the design of the study, this research used to conduct qualitative research which involved the exploration method through analytical instruments, interviews and descriptive survey method through a questionnaire instrument used in this study. Purposeful sampling technique was use in this research. The purposeful sampling technique was selected for this study because the sample selected from one population was according to the purpose of the study because the respondents were limited and only individuals involved with the formation of curriculum in the academic and skills at institutions of higher learning and skills institutions. Therefore, the population in this study consists of the Faculty Dean, Deputy Dean of the Faculty and Head of Faculty Department where they are individuals involved in the development of academic curriculum at Universiti Tun Hussein Onn Malaysia (UTHM). While in the field of skills, the population in this study was the Director of Institutions, Deputy Directors and Program Leaders from three skill institutes; Pusat Latihan Teknologi Tinggi (ADTEC), Kolej Kemahiran Tinggi MARA (KKTM) and Institut Kemahiran Belia Negara (IKBN). Based on information obtained from each institution involved, the total population of this study is 97 people. Because of the purposeful sampling technique used in this study, the total population of the survey population is 97 persons taken as a sample of the study. However, only 54 respondents gave feedback on distributed surveys. Table 1 shows the number of respondents from each institution.

Table 1 - Number of respondents from each institution

\begin{tabular}{cc}
\hline Institution & Number of Respondents \\
\hline UTHM & 37 \\
ADTEC & 5 \\
KKTM & 5 \\
IKBN & 7 \\
\hline
\end{tabular}

This study used an analysis document instrument. For an analysis document, it is divided into two parts. The first part, literary studies or literature sources are used as a source of research information for the synthesis of the study. The second part of an analysis document, the analyst analyses the Malaysian Qualifications Framework (MQF) document using the European Qualification Framework (EQF) and the Australian Qualification Framework (AQF) as a benchmark for determining level descriptions of the MQF which may be proposed for use for equivalency research between skills and academic according to the domain of knowledge, skills and competence.

This study made an analysis of the document of the MQF by examining the descriptive learning outcomes according to the qualification level and categorizing according to the eight sub-domains of learning outcomes in the 
MQF and the researchers categorized according to the domain of knowledge, skills and competence in accordance with the EQF. Table 2 shows the categories of three domains and eight sub-domains of learning outcomes used in determining qualification descriptions in the MQF.

\section{Table 2 - Domain categories and sub-domains of learning outcome determination of qualification description in} the Malaysian Qualifications Framework

\begin{tabular}{|c|c|}
\hline The European Qualifications Framework (EQF) & Malaysian Qualifications Framework (MQF) \\
\hline \multicolumn{2}{|c|}{ DOMAIN KNOWLEDGE } \\
\hline $\begin{array}{l}\text { - Extensive knowledge and the latest } \\
\text { - Critical Understanding } \\
\text { - Multi-discipline }\end{array}$ & - Knowledge of the field \\
\hline $\begin{array}{l}\text { - Problem solving } \\
\text { - Practical Relevance } \\
\text { - Innovation }\end{array}$ & $\begin{array}{l}\text { KILL } \\
\text { - Practical skills } \\
\text { - Problem solving and scientific skills } \\
\text { - } \text { information management skills and lifelong } \\
\text { learning } \\
\text { - Managerial and entrepreneurial skills }\end{array}$ \\
\hline \multicolumn{2}{|c|}{ DOMAIN COMPETENCE } \\
\hline $\begin{array}{l}\text { - Ability to work independently } \\
\text { - Communication } \\
\text { - Consideration of Social Issues and Ethics }\end{array}$ & $\begin{array}{l}\text { - Skills and social responsibility } \\
\text { - Value, attitude and professionalism } \\
\text { - Communication skills, leadership } \\
\text { teamwork }\end{array}$ \\
\hline
\end{tabular}

Subsequently, this study analysed each descriptive learning outcome by using two qualifying frameworks. It is EQF and the AQF where these two countries are countries that have implemented equivalence research through the APEL system. The findings of the analysis document are used as an item in the questionnaire. In terms of the reliability of the questionnaire, pilot study was conducted on 10 respondents among the former Dean, Deputy Dean and Head of Department at Faculty of Engineering Technology, Faculty of Electrical \& Electronic Engineering and Faculty of Technical \& Vocational Education at UTHM and five respondents among former Head of Department at Kolej Kemahiran Tinggi Malaysia (KKTM). The results of the pilot study showed that the items used in the questionnaire were at an excellent level. Table 3 shows the Alpha Cronbach values obtained in the questionnaire.

Table 3 - Alpha Cronbach values obtained in the questionnaire

\begin{tabular}{ccc}
\hline No. & Part of the questionnaire & Reliability values (Alpha Cronbach) \\
\hline 1 & B & 0.904 \\
2 & C & 0.931 \\
3 & D & 0.943 \\
\hline
\end{tabular}

Statistical Package for Social Science 20.0 (SPSS 20.0) is used to calculate the mean score and standard deviation for each level of approval of the qualification description for the Malaysian Qualifications Framework. The mean score obtained will be used as a measurement to determine the level of consent a qualification description of the Malaysian Qualifications Framework which may be proposed for use in the research of equivalence between skills and the academic according to the domain of knowledge, skills and competence whether at high, medium or low levels.

\section{Findings}

The analysis in the questionnaire was about descriptive analysis of each domain (knowledge, skills and competence) in the MQF. Table 4 is descriptors of Qualification Levels for 'Knowledge' domain. The Table 5 shows a descriptor of Qualification Levels for 'Skills' domain and Table 6 shows the qualification level description of 'Competence' domain in the MQF in detail. The value of mean score and standard deviation based on each description also on this table. 
Table 4 - Descriptors of Qualifications Levels for 'Knowledge' Domain

\begin{tabular}{|c|c|c|c|}
\hline \multicolumn{4}{|l|}{ KNOWLEDGE } \\
\hline Items/description & $\begin{array}{l}\text { MQF } \\
\text { Level }\end{array}$ & $\begin{array}{l}\text { Min } \\
\text { Score }\end{array}$ & STD \\
\hline Basic knowledge in the field of learning or work. & 1 & 4.70 & .461 \\
\hline $\begin{array}{l}\text { Knowledge and understanding of the basic facts in the field of learning or } \\
\text { work. }\end{array}$ & 2 & 4.74 & .442 \\
\hline $\begin{array}{l}\text { Knowledge of the facts, understanding, interpreting and using technical } \\
\text { information in a particular field of work and / or study. }\end{array}$ & 3 & 4.76 & .432 \\
\hline $\begin{array}{l}\text { using knowledge and understanding of broad facts and theories in a field } \\
\text { of work and / or learning. }\end{array}$ & 4 & 4.57 & .449 \\
\hline $\begin{array}{l}\text { using knowledge and understanding of broad facts and theories in } \\
\text { identifying the problem of a field of work and / or learning. }\end{array}$ & 5 & 4.74 & .442 \\
\hline $\begin{array}{l}\text { demonstrate knowledge and understanding of the theories and } \\
\text { fundamental principles of a field of study derived from advanced } \\
\text { textbooks and use them in ways that demonstrate professionalism in } \\
\text { work. }\end{array}$ & 6 & 4.52 & .504 \\
\hline $\begin{array}{l}\text { demonstrate advanced knowledge or understanding of advanced or } \\
\text { supplementary levels of bachelor and develop or use common ideas in the } \\
\text { context of research. }\end{array}$ & 7 & 4.54 & .573 \\
\hline $\begin{array}{l}\text { Knowledge and demonstrate a systematic and in-depth understanding of a } \\
\text { discipline as well as the mastery of research skills and methods related to } \\
\text { the field. }\end{array}$ & 8 & 4.56 & .572 \\
\hline
\end{tabular}

Table 5 - Descriptors of Qualifications Levels for 'Skills' Domain

\begin{tabular}{|c|c|c|c|}
\hline \multicolumn{4}{|l|}{ SKILLS } \\
\hline Items/description & $\begin{array}{l}\text { MQF } \\
\text { Level }\end{array}$ & $\begin{array}{l}\text { Min } \\
\text { Score }\end{array}$ & STD \\
\hline Basic skills in business processes and operations. & 1 & 4.61 & .492 \\
\hline $\begin{array}{l}\text { Basic cognitive and practical skills to use information and appropriate } \\
\text { techniques in scientific work processes, engineering design and problem } \\
\text { solving. }\end{array}$ & 2 & 4.67 & .476 \\
\hline $\begin{array}{l}\text { Cognitive and practical skills to use information and methods appropriate } \\
\text { for the scientific work processes, engineering design, operational decision } \\
\text { making and problem solving. }\end{array}$ & 3 & 4.69 & .469 \\
\hline Using the self-study skills for further education. & & 4.54 & .503 \\
\hline $\begin{array}{l}\text { Cognitive and practical skills in doing work and can make judgments, } \\
\text { decisions and problem solving. }\end{array}$ & & 4.54 & .503 \\
\hline $\begin{array}{l}\text { Master in learning skills to adapt to new ideas, processes and procedures } \\
\text { for career development and have entrepreneurial skills to generate their } \\
\text { own jobs. }\end{array}$ & 4 & 4.52 & .504 \\
\hline $\begin{array}{l}\text { Cognitive and practical skills in the workplace and can make judgments, } \\
\text { decisions and develop creative solutions to abstract problems }\end{array}$ & & 4.69 & .469 \\
\hline $\begin{array}{l}\text { Master the learning skills to adapt to new ideas, processes and procedures } \\
\text { for career development and have entrepreneurial skills to generate their } \\
\text { own jobs. }\end{array}$ & 5 & 4.67 & .476 \\
\hline $\begin{array}{l}\text { Highly skilled and able to argue in their respective fields of study as well } \\
\text { as having the techniques and capabilities of finding and using data for } \\
\text { complex decision making and problem solving. }\end{array}$ & 6 & 4.69 & .469 \\
\hline Study independently to pursue further studies with high autonomy. & & 4.57 & .602 \\
\hline
\end{tabular}


Items/description $\quad$ MQF Min

Level Score

STD

Highly skilled in making judgments, decisions and problem solving

4.70

.461

related fields of study and multidisciplinary contexts by using and

integrating knowledge and managing complex matters in a state of

absence or with limited information.

Learning skills to move forward with high autonomy.

.602

Highly skilled in making critical analysis, evaluation and synthesis of new and complex ideas by demonstrating the ability to generate, design, implement and modify most of the research process with scholarly integrity.

Contribute to the original research that widens the knowledge boundaries through deep dissertation that has been presented and maintained in accordance with international standards including writing in international refined publications.

\section{Discussion}

The findings of the qualification description for each domain in the Malaysian Qualifications Framework (MQF) min score and standard deviation for the entire qualification which can be proposed for the implementation of equivalence research between skills and the academic is at a very high level. It is because most the respondents strongly agree with the descriptors. In the MQF there is a description of the Level $1-3$ qualification stage, but there is no description specifying specifically for learning outcomes in the Descriptive Levels of Phase 1,2 and 3 contained in the MQF. This is in contrast to the Qualification Framework of several countries such as in Germany, Australia and South Africa which has adopted the APEL system and carried out an equivalency research between the academic of expertise in which EQF (2009) and AQF (2005) have specifically stated the Feasibility Phase for Levels 1, 2 and 3. Therefore, this study has constructed the proposed level of qualification description for Level 1 with EQF and AQF based benchmarking as no description of the level of qualification for Level 1 that is specific to the MQF. Based on the findings from the survey respondents' feedback, the level 1, 2 and 3 qualification descriptions of the three domains (knowledge, skills and competence) are appropriate for describing learning outcomes for each level.

In addition, MQF has a description of the 4th level qualification in particular, but the descriptions are not described in three domains (knowledge, skills and competence) for learning outcomes in the descriptions of Level of Qualification for level 4 to level 8 contained in MQF. This is in contrast to the Qualification Frameworks of some countries such as in Germany, Australia and South Africa which have adopted the APEL system and implemented equivalence research between the academic areas of expertise in which EQF (2008) and AQF (2005) have specifically stated the Descriptions of level 4 to level 8 which lists learning outcomes for that level according to the knowledge domain in the form of tables. Therefore, this study has developed a proposal for the qualification description for Level 4 in accordance with EQF and AQF as a benchmark because there is no description of the feasibility level description for Level 4 that is specific to the knowledge domain in the MQF. Based on the findings from the respondent's feedback, the descriptions of level 4 to level 8 qualifications for the three domains (knowledge, skills and competence) are ideal for describing learning outcomes for each level.

\section{Conclusion}

This study is to fulfil the needs of human capital development in our country. Students from the skills institute can hardly put themselves in an academic program. This skipper is forced to undergo a very high admission requirement set by the university even though it is necessary to start from the foundation and take very long learning time because the previous knowledge is not recognized. Equivalency research from skills to the academic is a development of relevant qualification mobility and is a requirement to apply because it needs to be taken seriously as it should be given opportunities for those in the area of skill to continue their studies at the academic level. This study was conducted to assist in establishing an APEL system in Malaysia as well as helping students from proficiency to continue lessons in academic. Furthermore, an improvement study needs to be made to convince the involved institutions to conduct equivalence research through the APEL system. Subsequently, based on the results of the study that have been discussed, the researcher has submitted several suggestions and recommendations to be considered by the parties. The suggestions and recommendations expressed in this study are expected to be addressed by certain parties in strengthening the APEL system in Malaysia. 
Table 6 - Descriptors of Qualifications Levels for 'Competence' Domain

\begin{tabular}{|c|c|c|c|}
\hline \multicolumn{4}{|l|}{ COMPETENCE } \\
\hline Items/description & $\begin{array}{l}\text { MQF } \\
\text { Level }\end{array}$ & $\begin{array}{l}\text { Min } \\
\text { Score }\end{array}$ & STD \\
\hline $\begin{array}{l}\text { Apply knowledge and skills in delivering information, ideas, problems to } \\
\text { experts and non-experts through effective communication with } \\
\text { supervision. }\end{array}$ & 1 & 4.65 & .482 \\
\hline $\begin{array}{l}\text { Apply knowledge and skills in delivering information, ideas and problems } \\
\text { to experts and non-experts through effective communication with some }\end{array}$ & & 4.67 & .476 \\
\hline limited autonomy. & 2 & & \\
\hline Teamwork and interpersonal skills that appropriate to the job & & 4.63 & .525 \\
\hline $\begin{array}{l}\text { Apply knowledge and skills in delivering information, ideas, problems } \\
\text { and solutions to specialists and non-specialists through effective }\end{array}$ & & 4.63 & .487 \\
\hline $\begin{array}{l}\text { communication by taking into account social, scientific and ethical issues } \\
\text { relevant to limited autonomy. }\end{array}$ & 3 & & \\
\hline $\begin{array}{l}\text { Teamwork and interpersonal skills relevant to employment and become } \\
\text { responsible members of society. }\end{array}$ & & 4.61 & .492 \\
\hline $\begin{array}{l}\text { Apply knowledge and skills in delivering information, ideas, problems } \\
\text { and solutions to experts and non-experts through effective communication }\end{array}$ & & 4.61 & .492 \\
\hline $\begin{array}{l}\text { taking into account social, scientific and ethical issues with moderate } \\
\text { autonomy. }\end{array}$ & 4 & & \\
\hline $\begin{array}{l}\text { Have self-confidence, teamwork and interpersonal skills appropriate to } \\
\text { the job as well as being a responsible individual in society. }\end{array}$ & & 4.67 & .476 \\
\hline $\begin{array}{l}\text { Apply knowledge and skills in delivering information, ideas, problems } \\
\text { and solutions to experts and non-experts through effective communication }\end{array}$ & & 4.74 & .529 \\
\hline taking into account social, scientific and ethical issues with autonomy. & 5 & & \\
\hline $\begin{array}{l}\text { Teamwork and interpersonal skills that are appropriate to the job as well } \\
\text { as being the responsible individual in society }\end{array}$ & & 4.59 & .520 \\
\hline $\begin{array}{l}\text { Apply knowledge and skills in delivering information, ideas, problems } \\
\text { and solutions to experts and non-experts through effective communication }\end{array}$ & & 4.61 & .461 \\
\hline $\begin{array}{l}\text { taking into account social, scientific and ethical issues with high } \\
\text { autonomy }\end{array}$ & 6 & & \\
\hline $\begin{array}{l}\text { Master the teamwork and interpersonal skills appropriate to the job as } \\
\text { well as be responsible individuals in society. }\end{array}$ & & 4.65 & .487 \\
\hline $\begin{array}{l}\text { Apply existing knowledge and skills in delivering the formula, knowledge } \\
\text { and rationality to experts and non-experts. }\end{array}$ & & 4.70 & .461 \\
\hline $\begin{array}{l}\text { Effective communication with regard to social, scientific and ethical } \\
\text { issues with a very high degree of autonomy and being a responsible } \\
\text { individual in society }\end{array}$ & 7 & 4.63 & .487 \\
\hline $\begin{array}{l}\text { Apply knowledge and skills in promoting technological, social and } \\
\text { cultural advances in knowledge-based society in academic and }\end{array}$ & & 4.63 & .487 \\
\hline professional contexts. & 8 & & \\
\hline $\begin{array}{l}\text { Communicate with colleagues, undergraduate community and the general } \\
\text { public on areas of expertise with very high autonomy as well as being } \\
\text { individuals in charge of society. }\end{array}$ & & 4.67 & .476 \\
\hline
\end{tabular}

\section{Acknowledgement}

The authors wish to acknowledge and appreciate the Research Management Centre (RMC) of the Universiti Tun Hussein Onn Malaysia (UTHM) for the financial support given to our research via the Fundamental Research Grant Scheme (FRGS) Vot. No. 1556, funded by the Ministry of Higher Education (KPT).

\section{References}

Australian Qualifications Framework Implementation Handbook (AQF) (2005). Retrieved on Mac 2, 2015 from http:// www.aqf.edu.au/implem.htm.

Georg. S. (2013). Permeability Between VET and Higher Education - A Way of Human Resource Development. Institut Technik Und Bildung (ITB), Universitat Bremen.Bremen: German 
Kaprawi, N. (2011). Leveraging Accreditation of Prior Experiential Learning (APEL) for Human Capital Development. Syarahan Perdana 2011. Universiti Tun Hussein Onn Malaysia.

Kementerian Pengajian Tinggi Malaysia. (2015). Kerangka Kelayakan Malaysia. Putrajaya: Kementerian Pengajian Tinggi Malaysia. Retrieved on Mac 2, 2015, from http://www.mqa.gov.my/portal2012/default/bm/mqf.cfm

Maclean, R. \& Pavlova, M. (2013). Vocationalization of Secondary and Higher Education: Pathways to the World of Work. UNESCO-UNEVOC: Revisiting Global Trends in TVET.

Md. Yunos, J. (2010). View from the field. UNESCO International Meeting on Innovation and Excellence in TVET Teacher/Trainer Education. 8-10 November 2004, Hangzhou, China.

Mohd Tahir, L., \& Mustafa, N. Q. (2009). Pendidikan Teknik dan Vokasional Untuk Pelajar Berkeperluan Khas. Retrieved on February 9, 2015, from http://web.usm.my/education/publication/JPP24_LokmanTahir_73-87.pdf

Mohammad, M. (2002). Credit for Work Experience. International Postgraduate Facilitator Management CENTRE, Malaysia.

Muskens, W. (2006). Permebility between VET and HE: The Experience of Module Level Indicator in Germany and its application in Austria. University Oldenburg.

National Qualifications Framework. 2009. European Frameworks: The Bologna Framework and the European Qualifications Framework. Retrieved on Mac 23, 2015 from http://www.nfq.ie/nfq/en/frame_action/europe.html

Wittig, W., Tutschner, R. \& Justin Rami. (2009). Accreditation of Vocational Learning Outcomes: European Approaches to Enhance Permeability between Vocational and Higher Education. Bremen. Nationale Agentur Bildung für Europa. 